\title{
Stefan Sołtyszewski
}

\section{Z przygotowań do II-go \\ Watykańskiego Soboru \\ Powszechnego}

Prawo Kanoniczne : kwartalnik prawno-historyczny 2/3-4, 371-377

1959

Artykuł został zdigitalizowany i opracowany do udostępnienia w internecie przez Muzeum Historii Polski w ramach prac podejmowanych na rzecz zapewnienia otwartego, powszechnego i trwałego dostępu do polskiego dorobku naukowego i kulturalnego. Artykuł jest umieszczony w kolekcji cyfrowej bazhum.muzhp.pl, gromadzącej zawartość polskich czasopism humanistycznych i społecznych.

Tekst jest udostępniony do wykorzystania w ramach dozwolonego użytku. 


\section{SPRAWOZDANIA RECENZJE KOMUNIKATY}

\section{Z PRZYGOTOWAÑ DO II-GO WATYKAÑSKIEGO SOBORU POWSZECHNEGO*}

Dnia 25 stycznia 1959 roku papież Jan XXIII oznajmił wobec Świętego Kolegium Kardynalskiego swój zamiar zwołania soboru powszechnego. Od tej chwili przy różnych okazjach i w ró inych miejscach papież zwracał się do duchowieństwa i do wiernych, aby modlili się $\mathrm{w}$ intencji przyszlego soboru.

Po wstępnych pracach na rzecz soboru, Ojciec św. Jan XXIII ustanowił Komisję Przedprzygotowawczą, której przewodniczącym został Sekretarz Stanu kardynał Tardini, a sekretarzem Mgr Felici. Zadaniem Komisji Przedprzygotowawczej, według słów Ojca św., było: „Nawiązać: odpowiednie kontakty z episkopatem katolickim różnych narodów, aby zasięgnąc rad i opinii, zebrać wnioski zredagowane przez dikasterie Kurii Rzymskiej, wykreślić linie generalne spraw, które będzie rozważał sobór, przy uwzględnieniu poglądów i studiów Wydziałów Teologicznych i Uniwersytetów Katolickich, opracować utworzenie różnych organów, których zadaniem będzie przygotowanie bliższe prac Soboru". Pierwsze plenarne posiedzenie Komisji Przedprzygotowawczej odbyło się 30 czerwca 1959 r.

Według dyrektyw Ojca św. Komisja Przedprzygotowawcza wysłała kwestionariusze prawie do 3 tysięcy przyszłych czlonków Soboru, celem zasięgnięcia ich opinii i sugestii. A więc byli zapytywani o zdanie nie tylko biskupi rezydencjalni, którzy są z prawa „Ojcami Soboru" z głosem decydującym, lecz również biskupi tytularni chociaż nie są ordynariuszami. Kodeks Prawa Kanonicznego mówi, że ci ostatni moga być zaproszeni na sobór i wtedy mają głos decydujący (kan. 223, § 2.). Wysłano również kwestionariusze do Wydziałów Teologicznych i Uniwersytetów Katolickich, które przedłożyły swe poglądy i studia craz do przełożonych nie tylkó zakonów wyjętych, ale i niewyjętych.

Do sierpnia 1959 r. $80 \%$ biskupów rezydencjonalnych odpowiedziało na przysłane kwestionariusze. Uniwersytety Katolickie i Wydziały Teologii Katolickiej miały odpowiedzieć w terminie do 30 kwietnia $1960 \mathrm{r}$. Według "Osservatore Romano" z dnia 10 czerwca $1960 \mathrm{r}$,

* Artykul opracowano na podstawie: Informations catholiques internationales, R. 1960, $\mathrm{Nr} \mathrm{Nr} 112,117,122,123,128,129$.

Zob. powyżej s. 13 i 14, K. P. K., kan. kan. 222 - 229, „De Concilio Oecumenico", w tlum. ks. S. Biskupskiego. 
w ciągu roku, episkopat z 62 krajów odpowiedział na kwestionariusze w 100\%. Material przesłany $w$ odpowiedzi na kwestionariusze jest nietyilko ogromny, ale i różnorodny. Byłoby koniecznym, powiedział Mgr Felici, zwołać 12 sołborów, aby go wyczerpać.

Komisja Przedprzygotowaweza zajęła się rozpatrzeniem i segregowaniem nadesłanych raportów. W lonie Komisji dziewięciu specjalistów zajęło się sporządzaniem szczególowej kartoteki rzeczowej nadesłanych materiałów. Oprócz tego Kongregacja Soboru powolala dziesięć komisji studiów przygotowawczych, dotyczących karności kościelnej, nowoczesnych środków apostolatu, administracji majątku kościelnego, sztuki sakralnej, archiwów i bibliotek, protestantyzmu, laikatu, katechizacji etc., które przedstawiały swoje propozycje. Ojciec Św oświadczył, iż $z$ wielką uwaga osobiście zbada sugestie i rady biskupów, propozycje św. Dikasteriów i poglądy oraz studia Uniwersytetów.

W swojej pierwszej encyklice „Ad Petri cathedram”, Jan XXIII określił cel Soboru. Definicję celu przypomina Papież w Motu proprio „Supremo Dei nutu", z dnia 5 czerwca 1960, w uroczystość Zesłania Ducha św. Głównym celem przyszłego Soboru, według slów Ojca Św. będzie: „Przyczynić się do wzrostu wiary katolickiej i do zbawiennego odrodzenia życia moralnego ludu chrześcijańskiego oraz przystosować karność kościelną odpowiednio do potrzeb naszych czasów. To stworzy bez wątpienia przecudowny obraz prawdy, jedności i milości, którego widok, mamy nadzieję, również dla tych, którzy są oddzieleni od tej Stolicy Apostolskiej, będzie miłym zaproszeniem do szukania i znalezienia tej jedności, o którą Jezus Chrystus tak gorąco modlił się do swego Ojca niebieskiego". (AAS, 41 (1959), 511).

Motu proprio „Supremo Dei mutu” ogłasza zamknięcie okresu przedprzygotowawczego, otwarcie okresu przygotowawczego i ustanowienie, dla przygotowania II-go Watykańskiego Soboru Powszechnego, Komisji Przygotowawczych. Zadaniem Komisyj będzie przestudiowanie wybranych przez Ojca św. Jana XXIII tematów, które uwzględniają życzenia Biskupów oraz propozycji, wysuniętych przez św. Dikasteria Kurii Rzymskich. Członkami tych Komisyj będą wybrani biskupi i wybitni duchowni, czy to spośród duchowieństwa świeckiego, czy zakonnego, powołani z różnych części świata, aby to także świadczylo o powszechności Kościoła. Do każdej komisji nadto będzie dołączonych kilku konsultorów, wybranych spośród ekspertów. Kakda komisja będzie miała swego przewodniczącego i sekretarza. Wszystkie te nominacje należą do Papieża. Zostało powołanych 10 Komisji które winny zająć się opracowaniem tematów na przyszły sobór, a mianowicie: 1) Komisja Teologiczna, której zadaniem jest wybór zagađnień dotyczących pisma św., Tradycji, wiary i obyczajów, - przewodniczący Kardynał Ottaviani, sekretarz O. Sebastian Tromp, S. J., Niemiec. 
2) Komisja dla spraw biskupów i zarządu diecezjami, - przewodniczący kardynał Mimmi (sekretarz Kongregacji Konsystorialnej), sekretarz arcybiskup Gawlina.

3) Komisja dla spraw związanych z karnością kleru i wiernych przewodniczący kardynał Ciriaci, prefekt Kongregacji Soboru, sekretarz O. Krzysztof Berutti, O. P., Włoch.

4) Komisja dla spraw zakonnych - przewodniczący kardynał Valeri, prefekt Kongregacji do spraw zakonnych, sekretarz O. Józef Rousseau, O. M. J. Kanadyjczyk.

5) Komisja dla dyscypliny Sakramentów - przewodniczący kardynał Massela, prefekt Kongregacji dla Sakramentów, sekretarz Rajmund Bidagor, S. J. Hiszpan.

6) Komisja liturgiczna - przewodniczący Gaetano Cicognani, prefekt Kongregacji świętnych Obrzędów, sekretarz O. Bugnini, Lazarysta, Włoch.

7) Komisja dla Studiów i Seminariów - przewodniczący kardynał Pizzardo, prefekt Kongregacji dla Uniwersytetów i Seminariów, sekretarz O. Aug. Mayer, O. S. B., Niemiec.

8) Komisja dla spraw Kościoła Wschodniego - przewodniczący kard. Amleto Cicognani, prefekt Kongregacji dla Kościoła Wschodniego, sekretarz O. Welykyi Bazykianin, Ukrainiec.

9) Komisja dla spraw Misji - przewodniczący kardynał Agagianian, pro-prefekt Kongregacji Rozkrzewiania Wiary, sekretarz biskup Matkrew, Anglik.

10) Komisja dla Apostolatu świeckich - dla wszystikich spraw dotyczących akcji religijnych i społecznej - przewodniczący kardynał Cento, sekretarz Mgr Glorieux, Francuz.

Wszystkie te komisje, za wyjątkiem ostatniej, odpowiadają przez swoją nazwę oraz ich przewodniczącego poszczególnym Dikasteriom Kurii Rzymskiej.

Oprócz dziesięciu komisji, papież Jan XXIII ustanowił dwa sekretariaty:

1) Sekretariat dla spraw dotyczących nowoczesnych sposoloów rozpowszechniania myśli ludzkiej. Przewodniczącym tego sekretariatu zostal Mgr Martin O'Connor, aktualny przewodniczący Komisji Papierskiej, sekretarzem Mgr Guerri, Włoch.

2) Sekretariat dla chrześcijan oddzielonych albo inaczej „Rada” specjaina $\mathrm{z}$ przewodniczącym kardynałem Bea i sekretarzem Mgr Willebrands, Holendrem. Ustanowiono go, mówi Papież w Motu proprio „Supremo Dei nutu”, ,celem okazania Naszej miłości i życzliwości względem tych, co nazywają się chrześcijanami, ale są odłączeni 
od Stolicy Apostolskiej, by i oni również mogli śledzic prace Soboru i łatwiej odnaleźć drogę do tej jedności, o którą Jezus Chrystus zanosil do Ojca niebieskiego tak gorąca modlitwą". Ta jedność, oświadczył Jan XXIII $w$ dzień Zesłania Ducha św., b.r. winna być jedrym z. najdrogocenniejszych owoców, zbliżającego się Soboru Watykańskiego, dla chwały Boga na ziemi i w niebie, dla radości powszechnej W spełnianiu się tajemnicy „Swiętych obcowania”. Z tego by wynikało, że dążność do jedności Kościolów jest drugim, a nie drugorzędnym celem II-go Watykańskiego Soboru.

Wreszcie Komisja Główna będzie koordynować prace wszystkich komisji oraz sekretariatów i przedstawiać ich wnioski papieżowi, aby mógł zatwierdzić tematy pod rozważania Soboru. $\mathrm{Na}$ czele Komisji Głównej stoi san Papież, sekretarzem jej został mianowany poprzedni sekretarz Komisji Przedprzygotowawczej, Mgr. Felici. Członkami jej są przewodniczący poszezególnych Komisji, niektórzy inni kardynalowie jak również niektórzy biskupi z różnych części świata. Komisja ta będzie liczyć 35 kardynałów, 25 arcybiskupów i 7 biskupów. Kościól Wschodni jest reprezentowany przez 4 patriarchów. Do Komisji Glównej zostali desygnowani również trzej przelożeni generalni zakonów, a mianowicie: Opat-prymas Benedyktynów, minister generalny Franciszkanów i generał Jezuitów. Również przydzieli się pewną liczbę doradców, wybranych spośród Biskupów i wybitnych duchownych. Cały swiat katolicki będzie uczestniczyl przez swoich przedstawicieli w Komisji Głównej, o czym świadczy sama jej formacja. Do niej bowiem wchodzą nie tylko liczni kardynałowie, przewodniczący poszczególnych Komisji Przygotowawezych, nie tylko kardynałowie przewodniczący Kcnferencji biskupich różnych krajów, ale również biskupi przewodniczący Konferencji biskupich aby $w$ ten sposób wszystkie kontynenty od starej Europy po wyspy Oceanni, były reprezentowane w Przygotowawczej Komisji Głównej. Dzięli współpracy tych przewodniczących Komisja będzie mogła zyskać doradców, którzy znają z bardzo bliska problemy swych krajów. Stąd w Komisji Głównej kraje Skandynawskie będzie reprezentowal przewodniczący Konferencji Krajów Skandynawskich. Tam natomiast, gdzie nie istnieje instytucja kanoniczna konferencji biskupich, naród będzie reprezentowal autorytatywny członek hierarchii; np. arcybiskup $z$ Wellingtonu reprezentuje Nową zelandie arcybiskup z Rańgunu - Birmę, arcybiskup z Tananarive - Madagaskar, wikariusz apostolski z Vinh-Cong VietNam i, być może, jeszcze inni. Do Komisji Glównej wchodzi również kardynał Rugambwa, przedstawiciel Afryki Centralnej, arcybiskupi Dakaru, Abidżanu i Brazville, przedstawiciele Afryki Zachodniej i Równikowej, wikariusz apostolski z Rabaulu, reprezentant Oceanii. To może oznaczać również reprezentację o charakterze regionalnym. Została również powołana komórka organizacyjna z przewodniczącym kardynałem Di Iorio na czele i sekretarzem Mgr Deskur, 
Polakiem. Zadaniem tej komórki są techniczne i ekonomiczne przygotowania do Soboru.

Powstaje pytanie: Jakie tematy będą przedmiotem obrad zbliżającego siç Soboru. Pierwszy wskaźnik możemy upatrywać w formacji Komisji ponieważ każda $z$ nich odnosi się do specjalnego zakresu karności czy nauki kościelnej.

Kardynał Tardini oświadczył, iż wedluż intencji Jana XXIII, zbliżający się sobór nie będzie ,prevalemento dogmatico". Wedỉug okólnika tegoż kardynała, wysłanego do Rektorów Uczelni Katolickich, na Scborze mogą być poruszane zagadnienia dogmatyczne, biblijne, liturgiczne, filozoficzne, moralne, prawne, duszpasterskie, socjalne etc. Może być również poruszana sprawa karności kleru i ludu chrześcijańskiego, seminariów i szkół oraz to wszystko, co wydaje się sprzyjać dobru Kościoła i dusz.

Na konferencji prasowej w dniu 30 października 1959 r. kardynał Tardini powiedział, że z nadesłanych odpowiedzi na kwestionariusz wyrikają liczne i różne tematy, proponowane na Sobór. Tak np. proponuje się nowe definicje dogmatyczne, potępienie zasadniczych błędów nowoczesnych, kwestie liturgiczne etc.

W. pismach i konferencjach różne osobistọ́si zastanawiają się nad tematami przyszlego Soboru. Najezęściej wysuwane są tematy, dotyczące współczesnych błędów, jedności Kościoła, problemów duszpasterskich, teologii biskupstwa etc. Do tej różnorodności tematów dochodza jeszcze, rzecz zrozumiala, odmienne zapatrywania na wiele kwestii.

Kardynał Montini, arcybiskup Mediolanu, przypuszcza, że pomiędzy tematami znajdą się $\mathrm{z}$ pewnością: kwestia dokladnego określenia wiadzy biskupiej, stosunki pomiędzy zakonami a biskupami, bardziej aktywny udzial świeckich w życiu Kościola. „W odróżnieniu od innych soborów, powiedział Kardynał Montini, II-gi Watykański Sobór zbiera się w momencie pokojowego i ożywczego życia Kościoła. Kościół dziś nie ma problemów negatywnych wewnętrznych do rozpatrywania, ma problemy pozytywne, wewnętrzne. To nie są herezje, schizmy, trudności dogmatyczne w łonie Kościoła, które zapraszają episkopat do zgromadzenia się przy papieżu; to jest raczej pragnienie skosztowania jedności, obowiązek przyczynienia się jeszcze większego do żywotności Kościoła, potrzeba uświęcenia i pogłębienia wewnętrznego, które wzywają Kościół nauczający do zebrania myśli (skupienia się)".

Ojciec św. Jan XXIII zdecydował ustalić tematy na przyszły Sobór, w drugim etapie przygotowań. Oprócz kwestii wybranych i zaproponowanych przez Papieża moga być w czasie trwania Soboru zaproponowane przez Ojców Soboru jeszcze inne i rozważane za aprobatą przewodniczącego Soboru (kan. 226). 
Jest rzeczą ciekawą, że w czasie I-go Soboru Watykańskiego, pomiędzy przeszło pięćdziesięcioma kwestiami przygotowanymi przez komisje i pominiętymi $w$ wielkiej części, nie figurowało zagadnienie nieomylności papieskiej $z$ którą związana jest nazwa Soboru. Jak wiadomo propozycja ta przyszła $z$ zewnątrz, to znaczy z Francji, aby, jak powiedział żartobliwie kard. Tardini „spłatać figiel gallikanizmowi. To są wspaniałe figle Opatrzności"!

Trudno przewidzieć kwestie, które będą traktowane przez Sobór, ale można postawić hipotezy na temat kryteriów, którymi będzie się posługiwal Papież przy ich wyborze.

Na wyibór tematów wplynie niewątpliwie ich zbieżnośc, zwlaszcza jeśli one pochodzą z różnych krajów. $\mathrm{Na}$ Soborze będą zapewne omawiane problemy dojrzałe, których rozpatrywanie, wydaje się ogólnie bardzo pilne. Nie można zapominać o troskach osobistych Jana XXIII, ponad którymi góruje niepokój o powrót odłączonych braci. Powołanie przez Papieża specjalnego Sekretariatu dla chrześcijan odłączonych świadczy, że sprawa jedności Kościola znajdzie się na porządku obrad. Dwa razy $w$ historii Kościola sobory były poświęcone specjalnie temu przedmiotowi. Mianowicie II Sobór Lioński, zwołany przez papieża Grzegorza X-go w roku 1274 i Sobór Florencki od roku 1439 do 1445 pod przewodnictwem papieża Eugeniusza IV.

Inicjatywa Jana XXIII zwołania nowego Soboru wzbudziła ogólne zainteresowanie $\mathrm{w}$ kościołach protestanckich, prawoslawnych, anglikańskich, starokatolickich, 83 krajów.

Patriarcha Antiochii i całego Wschodu oświadezyl, że tylko rada pań-prawosławna mogłaby na inicjatywę papieską udzielić „odpowiedzi prawomyślnej i powszechnie ważnej". Dotychczas tego rođzaju rada nie odbyła się i nie jest zapowiedziana.

Jeśli chodzi o Patriarchat Konstantynopolitański, sekretarz naczelny Swiętego Synodu oświadczył, że ,patriarchat powitał orędzie Jego Swiętobliwości Papieża i uważa je za pierwszy krok w kierunku zbliżenia pomiędzy dwoma Kościołami i przyszłej współpracy, z której cały świat chrześcijański będzie mógl odnieść korzyść". IMgr Iakovos, arcybiskup prawosławny grecki dla Ameryki nie widzi bliskiego polączenia się Kościołów, „zakładając, jak powiedział, że jesteśmy oddzieleni od IX-tego wieku".

Mgr. Baskir, arcybiskup Kościoła syryjskiego dla Ameryki Północnej uważa, że wstępne kontakty będą nieodzowne. Kościól ottodoksyjny oświadczył on ,przyjmie udział w Soborze, jeśli będzie zaproszony. To zebranie Kościołów jest wspaniałą idea i istnieją liczne moźliwości do zrealizowania jedności pomiędzy nimi. Znałem Jego Swiątobliwość i wierzą w Jego szczerość". Teolog rosyjski, Grzegorz Florencki wyraża opinię, że ,formalne spotkanie" Kościołów winno być poprzedzone długim przygotowaniem. 
Pastor protestancki Boegner, szef Kościoła reformowanego we Francji sądzi, że Sobór „będzie mógł zaznaczyć kapitalny postęp, jeśli wszystkie wielkie wyznania, odłączone od Kościoła rzymskiego, zostaną zaproszone". Lecz Dr Lilie, przewodniczący Swiatowej Federacji Luterańskiej uważa tę hipotezę za nieprawdopodobną.

Dr Fisher, arcybiskup Canterbury, szef Kościoła anglikańskiego diugo nie ogłaszal deklaracji w związku z zamierzonym Soborem. Dopiero 1 grudnia nastąpiło spotkanie dr Fishera $z$ Papieżem $w$ Watykanie. Dr Joost de Blank, arcybiskup Cap powiedział: „wszystko, co pomaga do położenia kresu w rozłączeniu jest dobrze przyjęte”. Dawny sekretarz Rady Kościoła anglikańskiego dla stosunków zewnętrznych utrzymuje: „Jeśli obserwatorzy mieliby być zaproszeni, winniśmy przyjąć zaproszenie"

Kardynał Bea, przewodniczący Sekretariatu dla chrześcijan oddzielonych, pragnie rozszerzyć z nimi kontakty, podezas przygotowań do Soboru. Będąc w New-Yorku, aby przyjąc doktorat honori causa na Uniwersytecie Fordham, kardynał Bea oświadczył, iż trzeba przedewszystkim poszukać stycznych punktów w chrześcijaństwie, które w następstwie winny się stać przesłankami kontaktów. Są niewątpliwie takie styczne punkty np. pomiędzy Anglikami i Kościołem Rzymsko-Katolickim. W Niemczech grupy protestantów poszukują wspólnej drogi, a mianowicie $w$ studiach biblijnych. Należy tu wspomnieć, że kardynał Bea jest wybitnym biblistą niemieckim, który zna szczególnie protestantyzm. Są kraje, gdzie są sprzyjające warunki zjednoczenia np. Niemcy, Szwajcaria, Francja i Anglia. W końcu, kardynał Bea dodał, że Sekretariat dla chrześcijan oddzielonych $w$ następstwie kontaktów, które będzie rozszerzal, przedstawi Ojcom Soboru punkt widzenia chrześcijan nie-katolików $\dot{i}$, że ci ostatni będą informowani o pracach Soboru na rzez jedności.

Po pierwszych reakcjach niekatolików Ojciec św. Jan XXIII wytyczył trzy etapy pracy na rzecz jedności Kościołów: „najpierw zbliżenie, później nawiązanie kontaktów, w końcu połączenie wielu braci oddzielonych". 